\title{
Neoliberal Kapitalizmde İstihdamİlişkilerinin Dönüşen Yapısı: Standart-Dışı Çalışma Formlarının Yükselişi
}

DOI: 10.26466/opus.609131

\begin{abstract}
Mevlüt Yılmaz*
*Dr. Öğr. Üyesi, Fırat Üniversitesi, İnsani ve Sosyal Bilimler Fakültesi, Merkez / Elazığ / Türkiye E-Posta: mevlutyilmaz@firat.edu.tr

ORCID: $\underline{0000-0002-8982-6778}$
\end{abstract}

Öz

Son dönemlerde, dünya genelinde istihdam ilişkilerinde yaşanan gelişme standart-dışı çalışma anlayışının yaygınlaşmasıdır. Artık standart istihdam ilişkileri erozyona uğramaktadır. Bu durumun ortaya çıkmasında dış kaynak kullanımı, belirli süreli sözleşmeler, part-time işler, geçici istihdam büroları ve bağımsız/kendi hesabına çalışma, evde çalışma, tele çalışma ve dijital platform odaklı çalışma gibi iş formlarındaki yükselişin önemli bir payı vardır. Standart-dışı çalışma ilişkileri, özelde çalışanları, işverenleri etkilemekle kalmamakta aynı zamanda genel işgücü piyasasını, ekonomiyi ve toplumu da etki altında bırakarak dönüştürmektedir. Bu çalışmada neo-liberal dönemde uygulanan istihdam politikalarının çalışma ilişkileri üzerindeki dönüştürücü gücüne yoğunlaşılarak standart-dışı istihdamın yaygınlaşması ve iş, işgücü ve istihdam piyasalarının temel karakteristiği haline gelişi konu edilmektedir. Çalışmada, istihdamın standart-dışılaşmasının hem kötü, güvencesiz işler olarak nitelendirilen çalışma şekillerini hem de dijital platform tabanlı yeni çalışma formlarını ortak kesen bir özellik olduğu vurgulanmaktadır.

Anahtar Kelimeler: Neoliberal İstihdam Politikaları, Esneklik, Standart-dışı Çalışma, Gig Ekonomisi, Dijital Çevrimiçi İşgücü Platformları 


\title{
The Transforming Structure of Employment Relations in Neoliberal Capitalism: The Rise of Non-Standard Work Forms
}

\begin{abstract}
Recently, non-standard conception of work has become widespread in employment relations around the world. Now, standard employment relations are being gradually destroyed. The increase in business forms such as, outsourcing, fixed-term contracts, part-time jobs, temporary employment agencies and independent/self-employment, homework, telecommuting and digital platform oriented working has a significant role in the emergence of this situation. Non-standard work not only affects the employees and employers in particular, but also affects and transforms the general labor market, economy and society. In this study, it was focused on the transformative power of employment policies implemented in the neo-liberal period on labor relations, and the spread of non-standard employment and its transform into the main characteristics of labor, work force and employment markets were discussed. In the study, it was emphasized that the non-standardization of employment is a common feature that intersects both working forms characterized as bad and precarious works, and new digital platformbased working forms.
\end{abstract}

Keywords: Neoliberal Employment Politics, Flexibilty, Non-Standart Work, Gig Economic,Digital Online Labour Platforms 


\section{Giriş}

Son yıllarda çalışma ilişkilerinde standart istihdam anlayışının erozyona uğraması dikkat çekicidir. Bu durumun ortaya çımasında part-time işler, belirli süreli sözleşmeler, geçici istihdam büroları vasıtasıyla kiralık iş/işçi bulma,taşeron çalışma, serbest meslekler/bağımsız çalışan sayılarındaki artış, kendi hesabına çalışma, tele çalışma, evde çalışma, çağrı üzerine çalışma, kitle kaynaklı çalışma (crowdwork), freelance çalışma gibi istihdam formlarının yükselişte olmalarının önemli bir payı vardır. $\mathrm{Bu}$ açıdan standart-dışı istihdam biçimlerinin yaygınlaşması, çalışma ilişkilerinin bilinen tüm standartlarının birer birer aşınması ya da ortadan kalkmasıyla yakından ilişkilidir.

Neoliberal çağda istihdam politikalarının dönüştürücü gücü esneklik merkezli uygulamalardır. Artık katı, standart, düzenli, istikrarlı işgücü/istihdam anlayışı, nostalji halini almaktadır. Yeni dönemde hız, kısa vadelilik, akışkanlık, seyyaliyet çalışma ilişkilerinin temelinde yer almaktadır. Bu durum çalışmaya/istihdama ilişkin tüm standartların radikal bir biçimde dönüştüğünü göstermektedir. İstihdam yapısının parçalanması ve çeşitlilik kazanmasıyla birlikte çalışmanın bilindik anlamlarının çalışan kesimler açısından geçerliliğini yitirmesi, onların daha belirsiz, istikrarsız, korunaksız bir sosyo-ekonomik yaşama içerilmesine yol açmaktadır.

Neoliberal istihdam anlayışının bir izdüşümü olarak standart-dışı çalışma ilişkileri, genel olarak iş yaşamında piyasa endeksli düzenlemeler, esnek çalışma uygulamaları, perifer işgücü, ömürsüz/kısa vadeli/ kullan at işler gibi semptomları genelleştirmektedir. Çalışma hayatındaki yapısal değişimlerle birlikte geçicilik (çok kısa ve hatta sıfır saatli sözleşmelerle), belirsizlik işgücü/istihdam pazarının standardı halini almaktadır.

Standart-dışı çalışma ilişkileri ve biçimlerinin yaygınlık kazanması yalnızca çalışma anlayışı açısından kötü ve riskli çalışma koşullarında, düşük ücret ve ödemede belirsizlikler yaşayan, çalışmanın sağladığ 1 fayda ve fırsatlardan yararlanamayan kısacası iş kalitesi düşük, vasıf gerektirmeyen güvencesiz işlerde istihdam edilenleri etkilememektedir. Aynı zamanda iyi şartlarda, dolgun ücretlerde çalışan, vasıflı işlerde istihdam edilen eğitimli işgücünün de standart-dışılığın yarattığı belir- 
siz, güvencesiz, istikrarsız bir iş yaşamını deneyimlemesine neden olmaktadır.

Günümüz toplumlarında enformasyon teknolojilerindeki gelişmeler dijitalleşme sürecini beraberinde getirmektedir. Dijitalleşme, başta ekonomi olmak üzere tüm alanlardaki faaliyetlerin örgütlenme biçiminideğiştirmektedir. Artık küresel dünyada iktisadi aktivitelerin önemli bir bölümü otomasyon sistemleri üzerinden yürütülmektedir. Bu süreçte çalışma, işgücü, istihdam yapılarının genel niteliği de dönüşmektedir. Dijital platformların her geçen gün etki alanının genişlemesi, işgücünün ve istihdam anlayışının yeni tarzda ele alınmasını ve çalışma formlarının çeşitlenmesini baskılamaktadır. Küresel dünyada, neoliberal kapitalizmin uyguladığı istihdam politikaları, çalışma ilişkilerinin standart yapılarını esneklik temelli dönüştürerek standart-dışıllğı iş, işgücü ve istihdam piyasasının temel karakteristiği haline getirmektedir. Dijital emek platformlarının yükselişiyle birlikte yeni çalışma şekillerinin ortaya çıkışı, çoğunlukla güvencesizliğin, belirsizliğin vasıflı-vasıfsız, eğitimlieğitimsiz geniş bir kesimi etkilemesine neden olmaktadır.

$\mathrm{Bu}$ çerçevede çalışmada dönüşen çalışma ilişkilerinin temel yapısı, neoliberal zamanlarda istihdam alanında yaygınlaşan standart-dışılığın çalışma kalıplarında meydana getirdiği değişimler ve iş, işgücü ve istihdam piyasaları üzerindeki etkileri analiz edilmektedir.

\section{Standart Çalışmadan Standart-Dışı Çalışmaya Dönüşen İstihdam İlişkileri}

Standart çalışma/istihdam ilişkileri, dünya savaşları sonrası dönemde, küresel ölçekte, ekonomik alanın yeniden yapılandırılması çerçevesinde geliştirilen ve uygulanan bir dizi politikanın sonucu olarak okunabilir. Bu dönemlerde çalışma yaşamı standart eylemler bütünü olarak sınırları ve süresi önceden belirlenmiş, işçi-işveren-devlet arasında garanti altına alınmış, istikrarlı ve güvenceli ilişkiler ağı etrafında organize edilmiş ve çalışma ilişkileri, ücretli çalışarak geçim güvencesinin sağlanması açısından değerlendirilmiştir.

Savaş yılları ve 2. Dünya savaşı sonrası dönemde, Fordizmin ortaya çıkışıyla birlikte hazırlanan uluslar arası işgücü düzenlemeleri paketi, "Standart İstihdam İlişkilerini" normatif bir istihdam modeli olarak oluş- 
turmaya odaklanmıştır. Standart istihdamın kökenleri ise 1919 'da başlayan Uluslararası Çalışma Örgütü (ILO) tarafından yapılan toplantılar, alınan karar ve tavsiyelere dayanmıştır (Vosko, 2010, s.51-52).

Standart çalışma/istihdam düzenlemeleri, belirli bir işveren ile standart bir iş yerinde belirli bir program dâhilinde (çoğunlukla tam zamanlı ve sürekli istihdam) karşılıklı bir beklenti içinde bir araya gelerek işverenin (Tablo 1'de A Örgütü) belirli bir ücret karşılığ çalışanın emeği ile değişmesi bağlamında ele alınmıştır. Standart çalışma ilişkileri vasıtasıyla çalışanların çoğu, geçimlerini sağlayan, sağlık ve güvenlik yasalarıyla kötü çalışma koşullarına karşı kendilerini koruyan, sömürüyü ve ayrımcılığı önleyen ve işsizlik sigortası yoluyla işsizliğin yarattığı mağduriyetleri en aza indiren bir yaşam elde ettiler. Ayrıca yönetimler analık/babalık, doğum gibi izinler ve Sosyal Güvenlik gibi ek imkânlar da sağlamıştır (Kalleberg, vd. 2000, s.257-258).

Vosko (2010, s.52-53)'ya göre, standart istihdam ilişkisi üç temel ve bir destekleyici ayaktan oluşmuştur. Bunlardan birincisi ikili istihdam ilişkisidir. Bilindiği üzere istihdam ilişkisi, tipik olarak işçi ve işveren arasındaki bir sözleşmeyle tanımlanır. İstihdam, ücretli çalışmanın farklı biçimleriyle ilişkili işgücü korumalarının belirlenmesinde merkezi önemdedir. Çünkü bu dönemlerde ücretli çalışan statüleri, çalışanların azami mesai saatleri, asgari ücret ve tehlikeli işleri reddetme hakkı, yasal tatiller, doğum izni, işsizlik sigortası, emeklilik maaşı gibi sosyal sigorta formları ve çoğu zaman toplu pazarlığa kadar değişen işgücü korumalarına erişimin bir ön şartı olmuştur. Çalışan statüleri, Fordist çalışma anlayışında sözleşmelerin standartlaştırılmasında ve sosyal sigortacılığın şekillenmesinde önemli rol oynamıştır. Bu durum özellikle çalışanların bir kısmının işverene yüksek seviyede bağlılığına ve uzun dönemli istikrara yardımcı olmuştur.

Standart istihdam ilişkisinin ikinci ayağını iş gücünün belirli bir zaman dilimi içinde işverene satılması olarak genelleştirilebilecek standartlaştırılmış çalışma zamanı temsil eder. Bu değişimin işverene sağladığ fayda doğrudan kontrol ve işverenin işçilerden farklı olduğuna yapılan vurgudur. Bu durum, işverenlerin çalışanlar üzerinde gerek iş gerekse işdışı yaşamalarının daha fazla denetlenmesinde etkili bir araç olarak kullanılır. Sonuçta standartlaştırılmış çalışma zamanı, düzenli ve senkronize bir ücretli çalışma günü (genellikle sekiz saat), çalışma haftası (yaklaşık 
40 saat) ve çalışma yılı (resmi tatiller ve ücretli izinler) belirleyerek çalışanların yaşamlarının eğitim, piyasada çalışma ve emeklilik gibi üç alana ayrılmasını sağlamıştır (Vosko, 2010, s. 54-55).

Standart istihdam ilişkisinin üçüncü temel ayağını ise sürekli istihdam oluşturur. İşverenlerin tek başına üretim araçlarına sahip olarak ve kontrol ederek üretim sürecinden kâr elde etmeleri garanti değildir. Çalışanlarla işbirliği temel önemdedir. Bunun için işverenler, emek ilişkisinin doğasında var olan çatışma ve gerilimleri en aza indirirken kârı maksimize etmeyi amaçlayan emek kontrolü formları geliştirirler. Böylesi bir açık uçlu iş ilişkisi, standart istihdamı destekleyen psikolojik sözleşmeyle bütünleşik risk paylaşımını güvence altına alır (Vosko, 2010, s. 58-59). Standart istihdam ilişkisini destekleyici ayağı ise örgütlenme özgürlüğü ve toplu pazarlık hakkı olarak değerlendirilir. Yüzyılın ortalarına kadar standart istihdam, temel olarak yetişkin bir erkek vatandaş tarafından tek bir işveren için yapılan tam zamanlı, sürekli ücret veya maaşlı istihdam anlamına geliyordu. ILO Anayasası 1919'da örgütlenme özgürlüğü ilkesini kabul etmiş ve 1944 'de ise Philadelphia Deklarasyonu bu ilkeyi yeniden onaylamış ve aynı zamanda toplu sözleşme hakkını da kabul etmiştir (Vosko, 2010, s. 61).

Ogura $(2005$, s. 10) ise yapmış olduğu karşılaştırmalı analizde standart istihdamı, uzun dönemli istihdam, tam zamanlı çalışma, yasa ve toplu sözleşmelerle güvence altına alınmış güçlü istihdam koruması, emekli aylığı, izin, sağlık gibi alanlarda sosyal yardımlar, ayni ve nakdi (ikramiye, gıda, barınma gibi) yardımlar bağlamında değerlendirmektedir.

Genel olarak ifade edildiğinde standart çalışma/istihdam ilişkisi ikili, belirsiz süreli iş sözleşmeleriyle garanti altına alınan, tam zamanlı ve düzenli çalışma süreleri ve ücretleriyle standartlaştırılmış ve sendikal/toplu sözleşme haklarının özgür bir alanına karşılık gelmektedir. Fordist çalışma anlayışının da genel çerçevesini oluşturan bu nitelikler çalışanların ciddi kazanımlar elde ettiğini ve çalışanlar açısından gerek iş gerekse de iş-dışı yaşamda istikrarlı, korunaklı alanların oluşmasına katkı sağladığını göstermektedir.

1940lardan 1970lere kadar geçen ara dönemde fordist çalışma anlayışı ile birlikte çalışma saati ve ücreti, asgari ücret seviyeleri ayrıca yaşlılık ve işsizlik sigortası gibi konularda yasalar tarafından korunma altına alınan 
çalışanların sayısında çarpıcı bir artış yaşanmıştır. İstihdam üzerindeki işverenlerin egemenliği toplu iş sözleşmesi vasıtasıyla sınırlandırılmış, çalışma şartları ve istihdam uygulamaları hükümetin sıkı denetimine girmiş ve bu durum yeni bir toplumsal sözleşmenin kurulması, gelişen güvenlik anlayışı ve bu dönemin ekonomik kazanımlarını sağlamlaştırmıştır. Çalışma ilişkileri, işveren davranışı kurallarının yayılımı ve iş kanunlarının yürürlüğe girmesiyle zamanla daha düzenli hale dönüşmüştür (Kalleberg, 2009, s. 4-5).

1970li yılların ortalarında başlayan değişimler, ülkeleri, işletmeleri ve çalışanları istihdamda daha fazla esneklik aramaya yönlendiren koşulları yaratmıştır. Böylelikle standart istihdam ilişkilerinde çözülmeler başlamıştır. Küresel ekonomik değişimler tüm alanlarda rekabet ve belirsizliği artırmıştır. Özellikle Avrupa ekonomilerinde tüm çalışanlar için fulltime, ücretli istihdamı sağlayacak işler üretememişlerdir. Standart-dışı çalışma anlayışına uyum, örgütler için üretimde uzmanlaşmayı kolaylaştıran, geçici çalışanların proje odaklı işler için birleşmelerini ve dış tedarikçilere güvenmelerini sağlayan iletişim ve enformasyon sistemlerindeki teknolojik gelişmelerle kolaylaşmıştır (Kalleberg, 2000, s. 342).

$\mathrm{Bu}$ dönemlerden itibaren ekonomik alanda Fordist örgütlenme tarzında yaşanan daralmalar küresel ölçekte sorunlar üretmiştir. Krizden çıkış yolu olarak kapitalist sistem yeni bir örgütlenme şekli üzerinde durmuştur. Kapitalist örgütlenmenin "Post-Fordist" evresi olarak nitelendirilen yeni dönem, esneklik temelinde standart tüm dinamikleri ve değerleri eleştirerek fordist anlayışın tasfiyesini hızlandırmış ve yeni bir yapılanmanın temelini oluşturmuştur. Bu yeni yapılanmayla, devlet uygulamalarında yeniden düzenlemeler, esneklik, artan istikrarsızlıklar, toplumsal gereksinimlerin ve sosyal güvenliğin özelleşmesi, bireysel/toplumsal ve kentsel/bölgesel düzeyde, her alanda, keskin rekabetler yaygınlaşmıştır. 1970li yılların sonlarına doğru yeniden yapılandırılan çalışma/istihdam anlayışının kapsamı, standart-dışı çalışma ilişkileri (kötü çalışma şartları, düşük ücretler, sosyal haklar ve güvenceden yeterince faydalanamama vb.) bağlamında değerlendirilir. İstihdam yapısının ve işgücü piyasasının parçalanması, esnek çalışma ve artan rekabet ile ücretlerin düşürülmesi, eğreti işgücünün yaygınlaştırılması ve emeğin kutuplaştırılması dönüşen çalışma ilişkilerinin temel yapısını teşkil etmektedir. 
40 yılı aşkın bir dönemde standart-dışı çalışma düzenlemeleri olarak hayata geçirilen geçici istihdam, sözleşmeli çalışma ve kısa süreli işler, çalışma ve istihdam ilişkileri üzerine yapılan araştırmaların odağında yer almayı sürdürmektedir. Standart-dışı istihdam ilişkileri genel anlamda alternatif çalışma düzenlemelerine (Polivka,1996 ve Sherer, 1996), piyasa odaklı düzenlemelere (Abraham, 1990), geleneksel olmayan istihdam ilişkilerine (Ferber ve Waldfogel, 1998), esnek görev düzenlemelerine (Abraham, 1988 ve Houseman, 1997), esnek çalışma uygulamalarına (Brewster vd. 1997) atipik istihdama (Cordova, 1986 ve Delsen, 1995 ve De Grip vd. 1997), perifer istihdama (Summers, 1997), savunmasız istihdama (Tregaskis vd. 1998), güvencesiz, kullan at işlere, istihdamın yeni formuna, şartlı istihdama atıfta bulunur (Kalleberg vd. 2000, s. 341; Appelbaum vd. 2019, s.22). Farklı çalışma şekillerini kapsayabilen standartdışı çalışma/istihdam ilişkisi, kavramsal açıdan ne olduğuna ilişkin tam bir fikir birliği olmamasına karşın standart istihdam ilişkisi bağlamında açıklanabilmektedir. Tablo 1'de temel nitelikleri bakımından standart çalışma anlayışı üzerinden standart-dışı çalışma düzenlemelerinin yansıma biçimleri ele alınmaktadır.

ILO'nun yayınladığ 1 raporda, standart-dışı istihdam ilişkisinin resmi bir tanımının olmadığ 1 ve daha çok tam zamanl, belirsiz süreli ve ikili bir istihdam anlayışı çerçevesinde ele alınan standart çalışma düzenlemeleri dişında kalan çalışma biçimlerini kapsadığı vurgulanır. ILO'nun "Dünyada Standart-dışı İstihdam: güçlüklerin kavranması, olasılıkların şekillendirilmesi" başlığını taşıyan bu rapora göre, standart-dışı istihdam, geçici istihdam, yarı zamanlı işler, geçici taşeron işçiliği ve özel istihdam büroları aracılığıyla oluşturulan diğer çalışma formları ve örtülü istihdam ilişkileri etrafında ele alınabilir (ILO, 2016a, s. 7). Standart-dışı ya da alternatif istihdam ilişkileri çağrı üzerine çalışanlar veya gündelik çalışanlar gibi şirket sözleşmesi ya da geçici istihdam büroları vasıtasıyla oluşturulan istihdam anlayışını da karşılayabilmektedir (Appelbaum vd. 2019, s.1-2). 
Tablo1. Standart/Standart-dışı Çalışma Düzenlemelerinin Karakteristikleri

\begin{tabular}{|c|c|c|c|c|c|c|}
\hline \multicolumn{7}{|c|}{ Çalışma Düzenlemelerinin Yansımaları } \\
\hline $\begin{array}{l}\text { Çalışma } \\
\text { Düzenlemelerinin } \\
\text { Türü }\end{array}$ & $\begin{array}{l}\text { Yasal } \\
\text { (de Jure) } \\
\text { İşveren }\end{array}$ & $\begin{array}{l}\text { Fiili } \\
\text { (de } \\
\text { Facto) } \\
\text { İşveren }\end{array}$ & $\begin{array}{l}\text { Yasal İşve- } \\
\text { ren Vasıta- } \\
\text { sıyla } \\
\text { Sürekli } \\
\text { İstihdam } \\
\text { Varsayımı }\end{array}$ & $\begin{array}{l}\text { Fiili İşve- } \\
\text { ren Vası- } \\
\text { tasıyla } \\
\text { Sürekli } \\
\text { İstihdam } \\
\text { Varsayımı }\end{array}$ & $\begin{array}{l}\text { Yönlen- } \\
\text { dirilmiş } \\
\text { Çalışma }\end{array}$ & $\begin{array}{l}\text { Çalışma } \\
\text { Saatleri }\end{array}$ \\
\hline Standart & $\begin{array}{l}\text { A } \\
\text { Örgütü }\end{array}$ & $\begin{array}{l}\text { A } \\
\text { Örgütü }\end{array}$ & Evet & Evet & $\begin{array}{l}\text { A } \\
\text { Örgütü }\end{array}$ & $\begin{array}{l}\text { Tam } \\
\text { zamanlı }\end{array}$ \\
\hline Part-time & $\begin{array}{l}\text { A } \\
\text { Örgütü }\end{array}$ & $\begin{array}{l}\text { A } \\
\text { Örgütü }\end{array}$ & Bazen & Bazen & $\begin{array}{l}\text { A } \\
\text { Örgütü }\end{array}$ & $\begin{array}{l}\text { Kismi } \\
\text { zamanlı }\end{array}$ \\
\hline $\begin{array}{l}\text { Çağrı üzerine/ } \\
\text { Günlük işgücü }\end{array}$ & $\begin{array}{l}\text { A } \\
\text { Örgütü }\end{array}$ & $\begin{array}{l}\text { A } \\
\text { Örgütü }\end{array}$ & Hayır & Hayır & $\begin{array}{l}\text { A } \\
\text { Örgütü }\end{array}$ & $\begin{array}{l}\text { Tam } \\
\text { veya } \\
\text { Kismi } \\
\text { zamanl1 }\end{array}$ \\
\hline $\begin{array}{l}\text { Geçici İstihdam- } \\
\text { büroları }\end{array}$ & $\begin{array}{l}\text { A } \\
\text { Örgütü }\end{array}$ & $\begin{array}{l}\text { A } \\
\text { Örgütü }\end{array}$ & Bazen & Hayır & A Örgütü & $\begin{array}{l}\text { Tam veya } \\
\text { Kismi } \\
\text { zamanlı }\end{array}$ \\
\hline $\begin{array}{l}\text { Şirket } \\
\text { Sözleşmesi* }\end{array}$ & $\begin{array}{l}\text { Şirket } \\
\text { sözleşmesi }\end{array}$ & $\begin{array}{l}\text { A } \\
\text { Örgütü }\end{array}$ & Evet & Hayır & $\begin{array}{l}\text { Şirket } \\
\text { sözleşmesi }\end{array}$ & $\begin{array}{l}\text { Tam } \\
\text { veya } \\
\text { Kismi } \\
\text { zamanlı }\end{array}$ \\
\hline $\begin{array}{lr}\text { Bağımsız } & \text { sözleş- } \\
\text { meler, } & \text { kendi } \\
\text { işinde çalışan }\end{array}$ & Kendi & $\begin{array}{l}\text { Müşteri } \\
\text { (ler) }\end{array}$ & Evet & Hayır & Kendi & $\begin{array}{l}\text { Tam veya } \\
\text { Kismi } \\
\text { zamanlı }\end{array}$ \\
\hline
\end{tabular}

*Sözleşmeli şirket çalışanları, yasal işverenleriyle standart bir iş düzenlemesine sahip olabilirler, ancak onların çalışma düzenlemeleri A Örgütü açısından standart dışıdır.

(Kalleberg, vd. 2000, s.258).

Geçici ve kısa vadeli çalışma anlayışı olarak değerlendirilen standartdışı istihdam ilişkisi, 1985-2016 yılları arası dönemde OECD ülkelerinin çoğunda artış göstermiştir. Standart-dışı çalışma düzenlemeleri, belirsiz süreli iş sözleşmeli, tam zamanlı, bağımlı bir istihdam anlayışını reddederek karışık dönemli sözleşmelerle çalışan, part-time işçileri ve kendi hesabına çalışanları içeren bir çalışma alanına sahiptir. Geçici işler; çağrı üzerine, gündelik veya mevsimsel çalışmayı, geçici taşeron işçiliğini ve sınırlı süre bağımlı istihdam çerçevesinde ele alınır. Part-time çalışanlar ise farklı ülke uygulamalarının yanında haftalık 30 saatten az çalışma anlayışına dayalı bir sınıflandırmaya tabidir. Serbest mesleklerde çalışma ise tüm bağımsız işleri kapsayan geniş bir kategoridir (OECD, 2018, s. 6870). 
Standart-dışı istihdam anlayışı bağlamında son yıllarda özel istihdam bürolarının ortaya çıkışıyla birlikte "kiralık işçi" statüsü de istihdam anlayışında yeni bir boyut olarak değerlendirilmektedir. Yine teknolojik alanda yaşanan gelişmelere paralel olarak internet tabanlı, sanal çalışma biçimleri de "dijital platform işleri" olarak kavramsallaştırılmakta ve 2010lu yıllardan itibaren çalışma hayatının dönüştürücü gücü olarak işgücü/istihdam pazarının yeniden örgütlenmesinde merkezi konuma gelmektedir.

\section{Neo-liberal Dönemde Standart-dışı Çalışma Biçimlerinin Yaygınlaşması}

OECD, ILO gibi küresel organizasyonlar, son yıllarda standart çalışma biçimlerinin düşüş trendi içine girdiği ve standart-dışı çalışma/istihdam ilişkileri olarak atıfta bulunulan anlayışın ise ciddi gelişmeler sergilediği konusunda hem fikirdir.

Standing (2017, s. 80-81)'e göre, geçici çalışma ilişkileri OECD ülkelerinin tümünde yeni işler için bir norm halini almaktadır. Kariyer yapılamayan standart-dışı işler hızla çoğalmakta ve bu türden istihdam olunan çalışan kesimlerin de daha uzun süreli işlerde çalışma adına herhangi bir nedenleri bulunmamaktadır. Örneğin Polonya'da yetişkin işçilerin $\% 27$ 'si ve 30 yaş ve altındakilerin \%65'i kısa vadeli işlerde çalışmaktadır. Yine Avustralya'daki işgücünün \%10'luk bölümü sözleşmeli çalışanlar tarafından karşılanırken geçici işlerde çalışanların oranı ise $\% 40$ civarındadır. Yeni Zelanda'da emek pazarının \%30'luk bir kısmı, güvencesiz çalışmadan etkilenmektedir.

Standart-dışı çalışma formları son 30-40 yılı aşkın bir zamanda hızlı bir artış trendi içine girmiştir. Geçici sözleşmeler, çoğu ülke çalışma yaşamının temel bir gerçekliği olmuştur. Bu durum özellikle genç çalışanlar arasında oldukça yaygındır. Örneğin OECD ülkelerinde 1980'de \%17 olmasına karşın 2016'da çalışanların yaklaşık dörtte biri 26 yaşının altında ve karışık dönemli iş sözleşmesine bağlı olarak çalışmaktadır(OECD, 2018, s. 69). Bu durum part-time işlerin yükselişte olduğunu göstermektedir.

20. yüzyılın sonlarına doğru tam zamanlı, kalıcı istihdamın önemi giderek azalmaktadır. Toplam istihdam içinde, full-time ücretli işgücünün 
oranı Avustralya'da \%83'ten \%71'e; Kanada'da \%78'den \%72'ye; 15 Avrupa Birliği (AB)üyesi ülkede ise\%88'den \%82'ye kaymıştır (Vosko, 2010, s. 74). Buna karşın birçok ülkede yarı zamanlı (part-time) işlerin toplam istihdamdaki oranı sürekli artmıştır. Kanada'da standart-dışı işlerin toplam istihdamdaki oranı 1989'dan 1994'e gelindiğinde \%28'den \%34'e fırlamıştır. Kanada'daki standart-dışı istihdamın \%45'ini ise part-time işler şekillendirmekteydi (Busby ve Muthukumaran, 2016, s. 4). Avustralya'da part-time çalışma anlayışının toplam işgücü piyasasındaki payı 1973-2006 yılları arasinda \%12'den \%24'e; Kanada'da \%10'dan \%18'e; 1983-2006 yılları arasında $15 \mathrm{AB}$ ülkesinde ise bu oran \%15'ten \%20'ye yükselmiştir. Geçici işlerde çalışanların toplam istihdamdaki oranı da 2006'ya kadar Kanada'da \%10; 15 AB ülkesinde ise \%11 civarındadır. Yine geçici istihdam büroları aracılığıyla karışık dönemli işlerde veya kendi hesabına çalışanların toplam istihdamdaki payları gün geçtikçe genişlemektedir (Vosko, 2010, s. 78-80). AB raporuna göre de 1985-2014 yılları arasında 15 AB ülkesi arasında Fransa, İşveç, Hollanda, İtalya gibi ülkelerde geçici istihdamın oranı kademeli bir biçimde yükselmiştir (Eurofound, 2017a, s. 37).

Sanayileşmiş ülkelerde yarı zamanlı çalışmanın "çok kısa saatler" ya da "sıfır saatli" sözleşmeler dâhil çağrı üzerine işler gibi çeşitlilikler gösterdiği ve gelişmekte olan ülkelerdeki geçici istihdam anlayışıyla örtüştüğü söylenebilir. Örneğin Birleşik Krallıkta 2015'te çalışanların \% 2,5'i sıfır saatli sözleşmelere bağlı olarak çalıştığı ve ABD'de ise işgücünün \% 10 'unu, düzensiz ve çağrı üzerine çalışanlar oluşturduğu ifade edilmektedir. Bangladeş ve Hindistan'da ücretli istihdamın yaklaşık \%67'si gelip geçici işlerde istihdam edilmekte; Mali ve Zimbabwe'de her üç çalışandan biri bu durumdadır. Avustralya'da ise her dört çalışandan biri gündelik, geçici işlerde çalışmaktadır. Asya ülkelerinde de parçalı, kurum aracılığıyla, alt sözleşmeli ya da taşeron çalışmanın çeşitli biçimleri yaygınlaşmaktadır. Hindistan'da imalat sanayinde 1970'lerde sözleşmeli işler (belirli bir işte geçici çalışma) 2011-2012 döneminde\% 34,7 düzeyine ulaşmıştır (ILO, 2016b).

2007 resesyonundan beri büyüyen standart-dışı istihdamın ana kategorilerinden biri de part-time çalışma ilişkisidir. İşsizlik oranlarının hızlıca arttığı AB üyesi ülkelerde gönülsüz part-time işlerde hızlı bir yükseliş söz konusudur. Birleşik Krallık'ta sıfır saat sözleşmeler ve gündelik, 
geçici sözleşmelerin ciddi artışı da bu eğilimin önemli bir göstergesidir. Böylesi bir eğilimin ortaya çıkmasında teknolojik gelişmelerle yaşanan ve çalışmanın dijitalleşmesi olgusuyla doğrudan ilişkilidir. Avrupa Komisyonunun yapmış olduğu bir araştırmaya göre, katılımcıların \% 74 'üne göre dijitalleşme, yarattığı işlerden daha fazlasının yerini alacaktır (Eurofound, 2017b, s. 19). Yani dijitalleşme merkezli çalışma, günümüz istihdam anlayışındaki başatlı̆̆ına paralel olarak oluşturacağı işlerden, daha çok çalışanın istihdam edilmesinde önemli roller üstlenecektir.

Küresel çalışma dünyasında yaşanan gelişme, dijitalleşmenin çalış$\mathrm{ma} /$ istihdam ilişkilerine olan etkisidir. Bu etki işlerin/mesleklerin ve çal1şanların sayısındaki değişim ile ilgili olduğu kadar işgücü piyasası ve iş/ işyeri organizasyonlarının dönüşümüyle de bağlantılıdır. Son yıllarda yasal bir istihdam ilişkisi olarak nitelendirilme konusunda dijital platform odaklı çalışma şekillerinde ciddi artışlar göze çarpmaktadır. Özellikle gelişmiş ülkelerde ve ülkemizde dijital platformlarda işverenlere/çalışanlara ilişkin vergi cezaları, sigorta primi vb. uygulama örnekleri bu yönde atılan adımlardır.

\section{İstihdamın Standart-dışılaşması: Sadece Güvencesiz, Kötü İşler de mi?}

İstihdam ilişkilerinde yaşanan dönüşüm ve standart-dışıllğın yaygınlaşması küresel ölçekte bir taraftan kalıcı işsizlikle karakterize edilen yeni yoksulluk şekillerinin türemesine, diğer taraftan da geleneksel olarak nitelendirilen proletaryanın yanında "prekarya" ve "fleksitarya" gibi yeni anlayışların da gelişmesine neden olmaktadır. Günümüzde istihdam anlayışının geçicileştirilmesi, güvencesizleştirilmesi veya esnekleştirilmesi çalışan kesimlerin ortak kaderi haline gelmektedir. Yakın zamanda küresel krizin 30 milyon insanı işsiz bırakacağı ve IMF başkanın bunun 100 milyonlara ulaşacağ emekçi kesimler arasında çalışma standartlarının aşınması neticesinde sadece güvencesiz, kötü şartlarda çalışanların bu durumdan etkilenmeyeceğini, aynı zamanda kalifiye eleman olarak görülebilecek ve esnek çalışmanın vurduğu orta sınıfın merkezinde yer alan vasıflı çalışanların önemli bir kısmının da etkileneceğini göstermektedir.

Burada "prekarya" olarak kavramsallaştırılan güvencesiz işlerde çalışanlar, emeğe ilişkin güvencelerden mahrum kesimleri karşılamaktadır. 
Buna göre yeterli derecede gelir getirici fırsatların oluşturulamadığı bir emek piyasası güvencesizliği, gelişi güzel işe alma ve işten çıkarma konusunda yasal yaptırımların yetersizliği, istihdamda belli bir statü kazanma ve bunu ilerletme fırsatının olmaması, çalışma şartlarını düzenleyici ve işçi sağlığını koruyucu yöntemlerin geliştirilememesi, ücret, sosyal güvenlik konusunda gelir güvencesizliği ve son olarak da örgütlenme hakkı çerçevesinde ortaya çıkan temsiliyet güvenliğinin ortadan kalkması (Standing, 2014, s. 26) gibi işgücünün temel yapısını etkileyen faktörler çalışma hayatında başat hale gelmektedir. Bu durum iş/meslek algısının değişmesini ve iyi/kötü, garantili/geçici, güvenceli/güvencesiz iş gibi dikotomilerin çalışma yaşamının bir gerçekliği olarak sıradanlaşmasına yol açmaktadır.

Kalleberg (2011, s. 15-16) 1970li y1llardan itibaren "iyi işler-kötü işler" arasındaki uçurumun giderek açıldığını ve durumun kronik bir hal aldığını belirtmektedir. Kutuplaşan ve güvencesizleşen istihdam sistemlerinde esneklik uygulamaları ve işverenlerin baskıları çerçevesinde ortaya çıkan ayrışma özellikle koruma sistemlerinin kaldırılması ve ekonomik yeniden yapılandırmalardan kaynaklanmaktadır. İş yaşamında çalışanlar arasında çevre/taşeron çalışanlar ile çekirdek çalışan kategorilerinin varlığı giderek yaygınlaşmaktadır.

Standart-dışı istihdamı eleştirenler, bu tür çalışma formlarının çoğunlukla iş kalitesi düşük mesleklerle eş tutulduğunu savunmaktadır. Çünkü iş kalitesi, sanayi toplumlarında sosyal tabakalaşmanın önemli bir boyutunu oluşturmaktaydı. O zamanlarda örneğin Marx, çalışma yaşamında kötü işler olarak nitelendirilen mesleklerin varlığının, işverenlerin mülkiyet edinmelerine ve üretim araçlarının kontrolünde işlevsel roller üstlenmesine imkân sağladığını ileri sürmüştü. 1940lara kadar bu deterministik anlayış, istihdamın saygınlığındaki çeşitliliği vurgulayan düşünceyle yer değiştirmiştir. Son zamanlarda istihdamın kompleks yapısı ve maddi talepler gibi boyutlardaki değişkenlik vurgulanmaktadır. Ancak iş kalitesindeki düşüklüğü "kötü işler" olarak karakterize eden bu yaklaşımda düşük kazanç, sağlık sigortası ve emeklilik maaşındaki gerilemeler çalışma ilişkilerinin ayırt edici özellikleridir. Bunun yanında istihdam güvencesizliği, örgütlenme faaliyetlerinin zayıflatılması, mesleki kompleksliğin gelişmesi ve istihdam maliyetlerinin kısılması gibi faktörlerde önemli rol oynamaktadır (Kalleberg vd. 2000, s. 259-260). 
Standart-dışı istihdam ilişkileri çalışma hayatında esneklik uygulamalarının genişlemesiyle paralel işleyen bir süreci kapsamaktadır. Bu süreç sadece güvencesiz-geçici-kötü şartlara bağlı işlere muhatap vasıfsız işgücünün yapısını bozmamakta, aynı zamanda eğitimli, deneyimli vasıflı işgücünün de durumdan pay almasına yol açmaktadır.

Standart-dışı istihdam biçimleri artık en yoksul ya da çaresiz kesimlerin ortak bir kaderi olmaktan çımakta ve orta sınıfların/beyaz yakalıların yaşamlarına sirayet eden banal bir durum halini almaktadır. "Kazanan hepsini alır" piyasası çok sayıda eğitimli insanı başarısızlığa mahkûm eden rekabetçi bir niteliğe bürünmektedir. İşten çıkarma ve yeniden tasarlama süreçleriyle birlikte geçmişte kapitalizmin daha çok emekçi sınıflara yaşattığı ani felaketler artık orta sınıftan insanlara da yaşatılmaktadır (Sennett, 2010, s. 125). Esnek çalışma formları bağlamında ortaya çıkan standart-dışılaşma, güvencesizleşme sadece mesleki bilgi ve deneyim gerektiren düşük vasıflı işlerle sınırlı değildir aynı zamanda beyaz yakalı, bilgi ve tecrübe gerektiren vasıflı işlerde de söz konusudur (Magdoff ve Magdoff, 2004). "Fleksitarya" olarak ifade edilen ve işgücü piyasası esnekliğiyle ortaya çıkan esnek çalışma şekilleri korumacı istihdam anlayışını olumsuz etkilemektedir.

İşverenler standart-dışı, esnek, güvencesiz, geçici, sözleşmeli çalışma formları yaratarak işgücü piyasalarında arz talep koşullarını kolaylıkla ayarlayabilme imkânına kavuşmaktadır. Özellikle dış kaynak kullanımı (outsourcing) yani ihtiyaç duyulan mal ve hizmetin dışarıdan tedarik imkânının varlığı ile eskiden güvenli olarak görülen yüksek ücretli, beyaz yakalı işler de dâhil olmak üzere tüm alanlarda dış kaynak kullanımı yaygınlaşmıştır (Kalleberg, 2009, s. 7-8). Bu durum işsizlik, güvencesizlik, standart-dışılık vb. olguların istihdam ilişkilerinde tüm kesimleri etkileme kapasitesine sahip olduğunu göstermektedir. Örneğin ABD'de beyaz yakalılar arasında işsizlik oranı 1970lerde mavi yakalıların üçte biri iken, 1990larda bu oran yarıya düşmüştür. Ayrıca ABD'de iş bulma oranı on yılda uzun süreli işsizlerde $\% 44$; en az lise mezunu ve iş idaresi yüksek lisansını yapanlarda\%45 gerilemiştir. Yine Almanya'da lise ve üniversite mezunları arasında iş arayanların oranı son bir yılda \%24,4 artmıştır. Bu durum vasıflı iş gücüne yönelik tehdidin 2009 kriziyle daha da arttığını ve özellikle kısa süreli sözleşmelerle çalışanların işsiz kaldıklarını göstermektedir (Bora ve Erdoğan, 2012, s. 18-19). Dünya Çalışma 
Örgütü'nün yayınladığı rapora göre, dünya genelinde çalışanların sadece dörtte biri istikrarlı bir işte istihdam edilmektedir. "Dünyada İstihdam ve Sosyal Görünüm 2015, İşin Değişen Doğası" başlıklı bu raporda, küresel işgücünün \%84'ünü kendi içinde barındıran bu ülkelerde çalışanların dörtte üçü, geçici ya da kısa sureli sözleşmelerle, çoğu zaman herhangi bir sözleşmenin bulunmadığ 1 kayıt dışı işlerde, kendi hesabına ya da ücretsiz aile işlerinde çalışmaktadır (ILO, 2015, s. 31). Bunun yanında beyaz yakalıların oluşturduğu mühendislik, doktorluk, akademisyenlik vb. birçok mesleki alanda istihdam ilişkileri daha esnek, geçici, güvencesiz ve istikrarsız bir yapıya bürünmektedir. Örneğin ABD'de 1973'ten 2005 yılına kadar olan dönemde akademi camiasında tam zamanlı görevlerde aşamalı bir düşüşün karşılığı olarak kısa-dönemli, geçici sözleşmelerde önemli artışlar yaşanmıştır (Kalleberg, 2009, s. 8-9). Benzer şekilde ülkemizde son dönemlerde istihdam edilen çalışabilir nüfusun önemli bir bölümünün sözleşmeli, proje odaklı, esnek çalışma biçimleri çerçevesinde istihdam edilmesi, bu durumun iş yaşamının bir gerçekliği olarak kabul gördügünü göstermektedir.

Dolayısıyla standart-dışı istihdam anlayışı, bir yandan taşeron çalışma, enformel işler, güvencesiz, geçici, atipik, eğreti çalışma biçimlerininuygulanabilirliğini artırırken diğer yandan da sözleşme tabanlı, proje odaklı çalışma, part-time işler, evde çalışma, tele çalışma, çağrı üzerine çalışma, dijital platform temelli çalışma gibi çeşitli çalışma formları oluşturarak bu sürecin daha da derinleşmesine neden olmaktadır.

\section{Gig Ekonomisi'nde Yeni İstihdam Biçimlerinin Standart-dışılaşması}

Son dönemlerde teknolojik gelişmelere paralel olarak ortaya çkan dijitalleşme olgusu istihdam ilişkileri üzerine etkileri bağlamında da birçok araştırmaya konu edilmektedir. Dijital devrim, mal ve hizmet üretimi, pazarlaması ve tüketiminin internet tabanlı sistemlerde, küresel ölçekte gerçekleştirilmesine atıfta bulunmaktadır. Artık yaşamın birçok alanında özellikle de ekonomik alanda faaliyetlerin büyük bölümü sanal platformlar üzerinden yürütülmektedir. Bu, küresel dünyada internete erişim oranlarındaki ciddi gelişmelerin sonucudur. 2010lu yıllarda dünya nüfusunun \%15'inin internete erişimi söz konusuyken bugün dünya nüfusunun \%40'ından fazlasının internete erişim sağlayabildiği ve bu 
trendin devam edeceği tahmin edilmektedir. Gelişmiş ülkelerde, 15-24 yaş aralığındaki gençlerin $\% 94$ 'ü, gelişmekte olan ülkelerde $\% 67$ 'si, az gelişmiş ülkelerde ise \%30'u internete erişim sağlayabilmektedir. Genç nüfusun \%80'ninden daha fazlası çevrimiçi (online) durumdadır (ITU, 2017 , s. 1-4). $2018^{\prime}$ de yayınlanan bir rapora göre ise, internet kullanıcılarının sayısı 2018' de \%7 artarak 4 milyarı aşmıştır. "Dijital yerliler" olarak adlandırılanların sayısı hızlı bir şekilde artmaktadır. Bunların ortak paydaları ise öğrenme, çalışma, iletişim ve eğlence gibi faaliyetleri için yeni teknolojileri ve sanal platformları mekân sınırlaması olmaksızın kullanabilmeleridir (Erdoğan ve Çiğdem, 2018, s. 236-237). Bu durum işgücünün de yeni tarzda ele alınmasını ve istihdam formlarının çeşitlenmesini beraberinde getirmektedir. Enformasyonun, eğitimin, inovasyonun, vasiflı işgücünün kutsandığı bir sosyo-ekonomik çevre, dijital işgücünü her geçen gün daha da yaygınlaştırmaktadır. Örneğin Amazon, Uber, Airbnb, Etsy, Linkedin, Facebook, İnstagram, Google, Yandex, TaskRabbit, Ebay vb. birçok şirket çevrimiçi dijital platformlar üzerinden hizmetlerini geliştirme bakımından ciddi atılımlar gerçekleştirerek işgücünün bu alanlara kaydırarak yoğunlaşmayı hızlandırmaktadır.

Dijital platformlar, merkezi olmayan networklar, büyük veri analizleri ve mobil dijital cihazların birleşiminden oluşmaktadır. Dijital işgücü platformları ise çalışma hizmeti işlemlerini algoritmik bir biçimde koordine eden dijital ağlardır. Bu platformların çalışma, istihdam ilişkileri üzerine etkileri farklılaşabilmektedir. Bir yandan işgücü piyasasına giriş konusunda engellerle karşılaşan kesimlerin (engelli, yaşlı, işsiz, öğrenci, göçmen vb.) emek pazarına içerilmesinde ciddi imkânlar sunmakta, diğer yandan da istihdam edilebilme, sosyal koruma ve temsiliyet konusunda belirsizlikler ve hatta dezavantajlı durumların ortaya çıkmasına neden olabilmektedir (Pesole vd. 2018, s. 7-8).

Dijital emek platformlarının oluşturduğu piyasa "Gig ekonomisi" nin temelidir. Gig ekonomisi, dijital teknolojileri kullanarak genellikle sınırları aşan projeler için ekipleri bir araya getiren ve dijital platformlar vasıtasıyla alıcıları ve satıcıları sorunsuz bir şekilde bir araya getiren ekonomi olarak tanımlanmaktadır (Eurofound, 2018). Gig ekonomisi özellikle istihdam alanında gelişen bir trend olarak değerlendirilmektedir. "2015 Freelancing in America" başlıklı araştırmaya göre, ABD'de toplam işgücünün \%34'ünün (yaklaşı 54 milyon çalışan) freelancer'lardan (kendi 
hesabına/bağımsız çalışanlardan) oluştuğu belirtilmektedir. Bu eğilim 2005'ten 2015'e kadar ABD ekonomisindeki alternatif çalışma düzenlemelerindeki artışın da kanıtıdır (BMO, 2018, s.3). ABD'de gig ekonomisine katılan çalışanların oranı $2005^{\prime}$ te $\% 10^{\prime}$ dan $2015^{\prime}$ te $\% 15,8^{\prime}$ e yükselmiştir (Katz ve Krueger, 2016, s.1; BMO, 2018, s.3; Etzioni, 2018, s.256). Benzer biçimde 2017' de yapılan bir araştırmaya göre, İngiltere' de 2008' de 1,4 milyon bağımsız çalışan varken 2016'da 2 milyona ulaşarak \%43'lük bir artış sergilemiştir. Bu sayının 1,77 milyonu freelance işleri ana işleri olarak, geriye kalanlar ise ikincil iş olarak tercih etmişlerdir. İngiltere'de freelance çalışanlar Birleşik Krallık toplam işgücünün \%6'sını oluşturmaktadır (Jenkins, 2017, s.4).

İnternet ve otomasyon tabanlı işgücü platformları arasında bir ayrım yapılabilir: Öncelikle açık websiteler üzerinden iş teklifi ve işlerin(genelde çevrimiçi tamamlanabilecek ve teslim edilecek işlerin ) tamamlanması süreçlerini içeren dijital platformlarda (genellikle çalışanları, hizmetlerinin son alıcılarıyla eşleştirmekle sınırlı)"kitle kaynak çalışma (crowdwork)" sistemlerinin varlığıdır. Diğeri isedaha geleneksel, fiziksel veya "gerçek dünya" görevlerini ve işlerini (bu işler, işin önemli yönlerini kontrol edebilecek şirketler tarafından yönetilen online platformlar vasıtasıyla organize edilir) içeren "talep üzerine çalışma (Work on-demand via apps)" sistemleridir (De Stefano, 2016, s.1).

Gig ekonomisi, geçici ve esnek çalışmanın yaygın olduğu ekonomik bir modeli karşılamakta ve bu ekonomide tam zamanlı çalışanların yerine bağımsız sözleşmeliler istihdam edilmektedir. Gig ekonomisinde çalışmayı karakterize eden birkaç özellik vardır: Öncelikle işler genelde belirli görevlere bölünür ve işçiler süregelen işlerden ziyade yaptıkları görevler için sözleşmeli olma eğilimindedirler. İşler bireysel olarak üstlenilir. Çalışanlar bağımsız yüklenicilerin tasnifine maruz kalırlar ve istihdam korumasının ve istihdamınasgari standartlarının herhangi birinden yararlanamayabilirler (Dosen ve Graham, 2018, s.2).

Dijital ve çevrimiçi platformlarda bağımsız çalışanlar, geleneksel işçilerden ayrılmaktadır. Eski çalışma anlayışında işçilerin daha çok kol gücüne dayalı işlerde sabitbir işyerine, işverene, ücrete ve sigorta sistemine bağlılı̆̆ı söz konusuydu. Yeni çalışma yaklaşımında ise beyin gücüne dayalı enformasyon ve teknoloji tabanlı sistemlerde/işlerde esnek- 
lik, akışkanlık, değişime hızlı ayak uydurma, yeni fırsatların peşinden koşma gibi faktörler çalışma ilişkilerinin merkezinde yer almaktadır.

Dolayısıyla, dijital çevrimiçi işgücü platformlarının ortaya çıkışı, son 10-20 yılı aşkın dönemde çalışma dünyasında meydana gelen en önemli dönüşümlerden biridir denilebilir. Dijital emek platformlarında çalışmak, çalışanlar açısından kendilerine uygun herhangi bir yerde, zamanda çalışabilme fırsatı sunmaktadır. Ancak bu türden işleri yaparken yeterli gelir, sosyal koruma ve diğer yardımlar konusunda bazı risklerle karşılaşabilmektedir (ILO, 2018, s. V). Örneğin küresel çapta hizmet sunan Amazon şirketi işlerinin önemli bir bölümünü dijital teknolojiler vasitasiyla görmektedir. Amazon Mechanical Turk (MTurk) global bir erişimle, talep üzerine 7/24 çalışma hizmeti sunan bir kitle kaynak kullanımı (crowdwork) platformudur. Burada gerek işletmelerin gerekse bireylerin işlerini ve süreçlerini sanal olarak yerine getirebilecek, kalifikasyonu gerçekleştirilmiş işgücüne erişim söz konusudur. Serbest çalışanlar için mikro işlerin ücret politikası, standart bir ücret uygulaması olmaksızın, işin zorluk derecesine göre belirlenmektedir. Çalışanlar ilk on gün deneme süreci olarak herhangi bir ücret alamamaktadırlar (MTurk, 2019).

Bu durum Gig ekonomisinin oluşturduğu istihdam alanının çalışanlar açısından sorunlu olduğunu göstermektedir. Çünkü Gig ekonomisiyle birlikte çalışanlar, istikrarsız çalışma saatleri ve ücret uygulamaları, çalışma hakları kapsamının daralması, emekli maaşı ve sosyal güvenliğe ilişkin belirsizlikler ve eğitim ve kariyer gelişimine erişimde eksikliklerle karşılaşması çerçevesinde iş güvencesizliği riskini (Eurofound, 2018) derin bir biçimde yaşayabilmektedir.

ABDli araştırmacılar Harris ve Krueger çevrimiçi dijital platformlarda "bağımsız çalışanlar"ın yasal ve ekonomik kategori olarak değerlendirilmelerini, örgütlenme ve toplu pazarlık gibi temel çalışma haklarının tanınması gerekliliğini savunmaktadırlar (2015, s. 9-10). Bu bağlamda ABD'de Freelancers Union 1995 yılından beri bağımsız çalışanların belirli haklar elde edebilmesi için mücadele vermektedir. Ülkedeki 57 milyon bağımsız çalışanı temsil eden ve kapsamlı gelişen bir örgüt olarak 375 bin üyeye hitap etmektedir (Freelancersunion, 2019). Bu türden faaliyetler, dijital emek piyasasında ortaya çıkabilecek hak kayıplarının önüne geçebilme ve çalışma hukuku açısından yeni gelişen alanlarda oluşabile- 
cek boşlukların doldurulması bakımından daha eşitlikçi bir bakışaçısının gelişimine imkân tanımaktadır.

\section{Sonuç}

Çalışma ilişkileri, modern öncesi dönemlerde daha çok temel ihtiyaçların karşılanmasını kapsayan gündelik faaliyetler açısından değerlendirilirken modern dönemlerle birlikte kapitalist çalışma anlayışı, standart eylemler etrafında organize edilmiştir. Modern çalışan, bir işe girdiğinde belirli bir işi, belirli bir işverenle, belirli bir işyerinde( genellikle fabrika) emekli olana dek aynı şartlar altında yerine getirmiştir. Modern sonrası dönemlerde ise çalışma ilişkilerinin bilindik tüm yapıları aşınmaya başlamıştır. Neoliberal kapitalist çalı̧̧ma/istihdam ilişkilerinin yükselişi, standart-dışılığın sıradanlaştığı, iş yaşamının standardı haline geldiği dönemleri karşılamaktadır.

$\mathrm{Bu}$ dönemde neoliberal istihdam politikalarıyla çalışma hayatında standart-dışılık yaygınlaşmaktadır. Neoliberal çağda istihdam anlayışı, çalışma ilişkileri ve işgücü piyasası esneklik uygulamaları etrafında yeniden yapılandırılmaktadır. İş, işgücü ve istihdam yapısının esnek, belirsiz, geçici, akışkan, eğreti bir nitelikte örgütlenmesi, standart dışılığın genelleşmesini ve gerek kötü işler diyenitelendirilebilecek vasıf gerektirmeyen, düşük kalitedeki işlerin gerekse de vasıf gerektiren, yüksek standarda sahip işlerin ortak özelliği halini almaktadır.

Son dönemlerde bilgi teknolojilerindeki muazzam gelişmelerle ilişkisi çerçevesinde dijitalleşme olgusu da çalışmanın anlamının, niteliğinin ve biçiminin kökten dönüşmesinde önemli bir paya sahiptir. Dijital işgücü platformları işin/istihdamın bilindik yapılarını parçalayarak çeşitlilik üretmekte ve yeni işlerin ortaya çıkmasına neden olmaktadır. Bu bağlamda gig ekonomisinin gelişimiyle ortaya çıkan internet tabanlı çevrimiçi çalışma anlayışı, küresel ölçekte her geçen gün etki alanını genişleterek çalışma yaşamında güvencesizliğin, belirsizliğin yeni/sanal mekânları haline gelmektedir. Neoliberal kapitalizm açısından eğitim politikalarıyla okuma yazma oranlarındaki ciddi artışların sağlanması, otomasyon teknolojilerinin ilk kademeden itibaren eğitimin bir parçası haline getirilmesi, internet kullanımının hızlı yayılımı vb. gelişmeler çalışabilecek işgücünün yeniden üretiminde fonksiyoneldir. Bu açıdan 
günümüz bilgi teknolojileri çağında belirli bir eğitim kariyerine ve deneyime sahip, vasıf gerektiren dijital işgücü platformlarının hinterlandlarını sürekli genişletmesi çalışma ilişkileri açısından da önemli bir gelişmedir.

Dijital işgücü platformları yarattı̆̆ katma değer açısından çalışanlar, işverenler ve devlet nezdinde bir dizi avantajlara sahip olabilir. Ancak çalışanların sömürülmesi, ücret konusunda belirli standartlardan yoksunluk, ücret ödemedeki belirsizlikler, örgütlenme ve toplu pazarlık haklarındaki aşınmalar gibi birçok konuda ciddi dezavantajlı bir çalışma anlayışını beraberinde getirmektedir. Dijital platformlarda çalışma düzenlemelerine ilişkin hukuki boşlukların varlığı da gerek işverenleri gerekse yönetimleri zor durumlarla yüzleştirebilmektedir. 
EXTENDED ABSTRACT

\title{
The Transforming Structure of Employment Relations in Neoliberal Capitalism: The Rise of Non-Standard Work Forms
}

\author{
Mevlüt Yilmaz \\ Firat University
}

Recently, non-standard conception of work has become widespread in employment relations around the world. Now, standard employment relations are being gradually destroyed. The increase in business forms such as, outsourcing, fixed-term contracts, part-time jobs, temporary employment agencies and independent/self-employment, homework, telecommuting and digital platform oriented working has a significant role in the emergence of this situation. Non-standard work not only affects the employees and employers in particular, but also affects and transforms the general labor market, economy and society. In this study, it was focused on the transformative power of employment policies implemented in the neo-liberal period on labor relations, and the spread of non-standard employment and its transform into the main characteristics of labor, work force and employment markets were discussed. In the study, it was emphasized that the non-standardization of employment is a common feature that intersects both working forms characterized as bad and precarious works, and new digital platform-based working forms.

It is remarkable that standard conception of employment in labor relations has been gradually destroyed in recent years. The fact that employment forms, such as part-time jobs, fixed-term contracts, finding work/worker for hire through temporary employment agencies, subcontract working, increase in self-employment/independent workers, self-employment, telecommuting, homework, on-call working, crowdwork and freelance working, are on the rise has a significant role in the emergence of this situation. In this regard, the spread of non- 
standard forms of employment is closely associated with the erosion or disappearance of all known standards of labor relations one by one.

In the neoliberal era, the transformative power of employment policiesand employmentrelations in transformation from standard work to non-standard workis flexibility-centered applications. Now, solid, standard, regular and stable conception of employment/work force becomes a nostalgia. Speed, short-termism, mobilization and fluidity are on the basis of labor relations in the new period, which indicates that all standards related to work/employment has been radically transformed. The fact that the familiar meanings of work lose their validity lose validity in terms of the working class along with the fragmentation and diversification of the employment structure causes them to be included in a more uncertain, unstable and unprotected socio-economic life.

As a projection of neoliberal conception of employment, non-standard labor relations generalize the symptoms such as market indexed regulations, flexible working practices, peripheral work force, fugacious/short term/disposable jobs in general. Along with the structural changes in business life, transience (with very short and even zero hour contracts) and uncertainty become the standard of employment/labor market.

The spread of non-standard working relations and forms does not only affect those who cannot benefit from the benefits and opportunities of work, have low wages and uncertainties in payment under poor and risky working conditions, in short, those who are employed in precarious jobs with low work quality that do not require qualifications. It also causes educated workforce who are employed in better conditions and in qualified works with high salary to experience an uncertain, precarious and unstable business life created by non-standardization.

The developments in information technologies in today's societies bring along the digitalization process, as well. Digitalization changes the organizational forms of the activities in all fields, especially economic activities. Now, a significant part of economic activities in the global world are performed through automation systems. In this process, the general quality of working, labor and employment structures is also being transformed. The expansion of the impact of digital platforms day by day suppresses the new approach of the workforce and the conception of employment and the diversification of forms of work. 
As a result, in the global world, the employment policies implemented by neoliberal capitalism make non-standardization the basic characteristics of the labor, work force and employment market by transforming the standard structures of labor relations based on flexibility. The emergence of new forms of working along with the rise of digital labor platforms usually causes precariousness and uncertainty to affect a wide range of skilled and unskilled, educated-uneducated individuals.

\section{Kaynakça / References}

Appelbaum, E. K., Arne, L., ve Rho, Hye J. (2019). Nonstandard workarrangements and older Americans. 2005-2017,CEPR, Economic Policy Institute View this report accessed on epi.org/162673.

BMO. (2018). Gig economy. BMO Wealth Management, s.1-9. 23.07 .2019 tarihinde https://wealth.bmoharris.com/media/resource pdf/18-0996 BMO Wealth Insight Gig Economy US Ev4.pdf adresinden erişilmiştir.

Bora, T. ve Erdoğan, N. (2012). Cüppenin, kılıcın ve kalemin mahcup yoksulları. yeni kapitalizm, yeni işsizlik ve beyaz yakalılar( Bora, T. - Bora, A. - Erdoğan, N. - Üstün, İ. Ed.) "Boşuna mı Okuduk?" Türkiye'de Beyaz Yakalı İssizliği içinde(s. 13-44),İstanbul:İletişim Yay.

Busby, C. ve Muthukumaran, R. (2016).Precarious positions: Policy options to mitigate risks in non-standard employment. C.D. Howe Institute, Toronto, Ontario.

De Stefano, V. (2016). The rise of the "just-in-time workforce : On-demand work, crowdwork and labour protection in the "gigeconomy".International Labour Office, Inclusive Labour Markets, Labour Relations and Working Conditions Branch. - Geneva: ILO, 2016 Conditions of work and employment series; No. 71)

Dosen, I. ve Graham, M.(2018). Labour rights in the gig economy An Explainer. Research Note No. 7, June, Research \& Inquiries Unit, Parliamentary Library \& Information Service, Parliament of Victoria, s. 1-24.

Bora, T. ve Erdoğan, N. (2012). Sancılı dil, hadım edilen kendilik ve aşınan karakter. ( Bora, T. - Bora, A. - Erdoğan, N. - Üstün, İ. Ed.) "Boşuna mı Okuduk?" Türkiye'de Beyaz Yakalı İsssizliği içinde(s. 13-44). İstanbul:İletişim Yay. 
Erdoğan, E. ve Çiğdem, S. (2018).Gig ekonomisi ve freelance işgücünün yükselişi: Freelancer.com üzerinden bir değerlendirme.(Ed. Erdoğan, E.),Sakarya Üniversitesi Çalışma Ekonomisi ve Endüstri İlişkileri Seçme Yazılar-II içinde (s. 229-261), Sakarya Yay. Sakarya..

Etzioni, Amitai (2018). “Benefits for Gig Workers, Challenge, 61:3, s.255-268.

Eurofound (2018).Gig economy. 18.07.2019 tarihinde https://www.eurofound.europa.eu/observatories/eurwork/industrial-relationsdictionary/gig-economy adresinden erişilmiştir.

Eurofound (2017a). Non-standard forms of employment: Recent trends and future prospects. Eurofound, Dublin.

Eurofound (2017b). Aspects of non-standard employment in Europe. Publications Office of the European Union, Luxembourg.

FREELANCERSUNION (2019). Freelancersunion, About.23.07.2019 tarihinde https://www.freelancersunion.org/about/ adresinden erişilmiştir.

ILO (2018).Digital labour platforms and the future of work.Towards decent work in the online worldInternational Labour Office - Geneva: ILO.

ILO (2016a).Non-standard employment around the world. Understanding challenges, shaping prospects, International Labour Office - Geneva: ILO.

ILO (2016b).Standart dişı işlerin kalitesinin artırılması için düzenleyici reformlar gerekiyor. 26.02.2019 tarihinde https://www.ilo.org/ankaraLnews/WCMS 534965/lang--tr/index.htm adresinden erişilmiştir.

ILO (2015). World employment and social outlook 2015, The changing nature of jobs / International Labour Office - Geneva: ILO.

ITU (2017). ICT Facts and Figures 2017. Geneva, 1-8.19.07.2019 tarihinde https://www.itu.int/en/ITUD/Statistics/Documents/facts/ICTFactsFig ures2017.pdfadresinden erişilmiştir.

Jenkins, K. (2017). Exploring the UK freelance workforce in 2016. Small Business, Research Centre, London, s. 1-8. 25.07.2019 tarihinde https://www.ipse.co.uk/uploads/assets/uploaded/de84dfb7-283a4c26-ba446f95f5547c1f.pdfadresinden erişilmiştir.

Jenkins, K. (2018). The rise of freelancing, feature. 25.07.2019 tarihinde http://www.myfreelancerguide.com/the-rise-of-freelancing-feature/ adresinden erişilmiştir.

Kalleberg, A. L. (2011). Good jobs, bad jobs: The rise of polarized and precarious employment systems in The United States, 1970s to 2010s. Russell Sage Foundation, New York. 
Kalleberg, A. L. (2009).Precarious work, insecure workers: Employment relations in transition. American Sociological Review, 74,1-22.

Kalleberg, Arne L. (2000).Nonstandart employment relations: Part-time, temporary and contract work. Annual Revival Sociology, 26, 341-65.

Kalleberg, A. L., Reskin, B. F. and Hudson, K. (2000).Bad jobs in America: Standard and nonstandard employment relations and job quality in the United States.American Sociological Review, 65(2), 256-278.

Magdoff, F. ve Magdoff, H. (2004). Disposible Workers. Monthly Review, 55(11), 09.07.2019 tarihinde http//www.monthlyreview.org/ 0404magdoff.html adresinden erişilmiştir.

MTurk (2019). Amazon mechanical turk. Overview, 22.07.2019 tarihinde https://www.mturk.com/ adresinden erişildi.

Ogura, K. (2005).International comparison of atypical employment: Differing concepts and realities in industrialized countries. Japan Labour Review, 2(2), 5-29.

OECD (2018). Job creation and local economic development 2018.Preparing for the Future of Work, Paris:OECD Publishing,

Pesole, A., Urzí Brancati, M.C, Fernández-Macías, E., Biagi, F., González ve Vázquez, I. (2018). Platform workers in Europe.Luxembourg:Publications Office of the European Union,.

Sennett, R. (2010). Karakter aşınması.Yeni kapitalizmde işin kişilik üzerindeki etkileri.(Çev. B. Yıldırım), (4.Basım), İstanbul:Ayrıntı Yay.

Harris, S. D. ve Krueger,A. (2015). A proposal for modernizing labor laws for Twenty-First-Century work: The independent worker, The Hamilton project. Brookings Inst., Washington DC, s. 1-40.

Standing, G. (2017). Prekarya Bildirgesi, Hakların kısılmasından yurttaşlı̆̆a. (Çev.S.Çınar ve S. Demiralp), İstanbul:İletişim Yay.

Vosko, Leah, F. (2010). Managing the Margins: Gender, citizenship, and the international regulation of precarious employment.New York:Oxford University Press.

\section{Kaynakça Bilgisi / Citation Information}

Yılmaz, M.(2019). Neoliberal kapitalizmde istihdam ilişkilerinin dönüşen yapısı: Standart-dışı çalışma formlarının yükselişi. OPUSUluslararası Toplum Araştırmaları Dergisi, 14(20), 1710-1734. DOI: 10.26466/opus.609131 